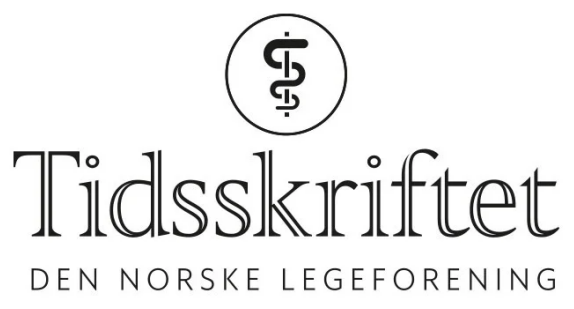

\title{
Alkohol mot influensa
}

TIDLIGERE I TIDSSKRIFTET

JULIE DIDRIKSEN

julie.didriksen@tidsskriftet.no

Tidsskriftet

Spanskesyken traff Norge i 1918, og våren 1919 publiserte Tidsskriftet et «Influenza-nummer». Da var vi i tillegg allerede et par år inn i forbudstiden, og «alkoholspørsmålet» ble hyppig diskutert både i Tidsskriftet og andre steder. Nå begynte det også å dukke opp historier om at alkohol kunne beskytte mot influensaviruset. En lege ved Ullevål sykehus innledet temanummeret, utgave 6, med en artikkel om blant annet dette. Under følger et utdrag (Tidsskr Nor Lægeforen 1919;39: 217-21).

Influenza - særlig alkoholbehandlingen. 


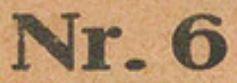

1919

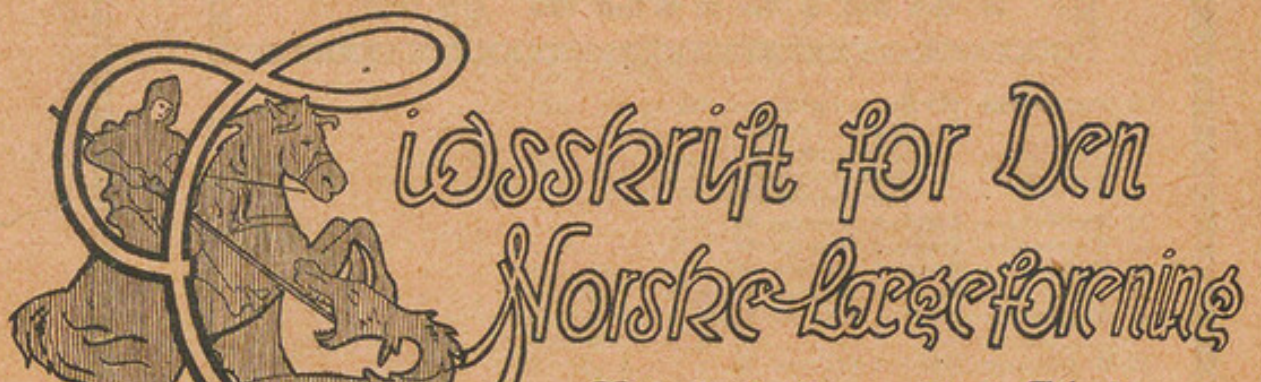

Tidsskrift for praktisk Medicin

- Ny Rakke -

Redigert av overlage P. AASER og RS. HANSSON lage, generalsekretar

\begin{tabular}{c|c||c|}
\hline Nr. 6 & KRISTIANIA, 15de MARS 1919 & 39. aargafig. \\
Indhold: Influenza særlig alkoholbehandlingen. Av K. J. Figengegl. S. 217. -
\end{tabular}
Den espanske syke i Arendal 1918. Nils Barth. S, 221. OOmking influenzaen, dens behandling. Av J. Voss. S. 230. - Behandling av inflûfu, - gjærbehandling. Av P. R. Vaage. S. 230. - Kasuistiske meddelelser to Rikshospitalets avdeling for hudsygdomme. Ved E. Bruusgaard. (Forts, fra nr, 4) S. 231. Til lysbehandlingen i Norge. Av J. Reinhardt Natvig. S. 234. Aversigter, referater og pragtisk notiser. S. 236. - Hygieniske meddelelser og gocil hedicin: Sykehus for kirurgisk-tuberkulose i Kristiania. - Indlands- eller kysthofpital? Fra C. M. F. Sinding-Larsen. S. 242. Lxgeforhold ute og hjemme, Wbeforsikring etc. S. 248 . - Ansæettelsesvilkaar for sykehuslæger. Av O. Borcgrevink. S. 250. - Meddelelser om literatur ang. barneforsorg, skolehygiene ete 1 S. 254 - Kraftsykehuset - bidrag fra læger. S. 255. - Ind. betaltebidrag,til Reservefondet. S. 256. - Bidrag til Reservefondet. S, 257. - Reste. rende bidraf for $1916-1917$ til Reservefondet. S. 257. - Indbetalte kontingenter til Den notske fegeforeninger. S. 257. - Dødsfald i utlandet. S. 258. - Blandede meddelelsen S. 260.

Meddelelser fra Den norske lageforenings bureau: Officielle meddelelser Universitetsefterretninger. Specielle stipendier. Ledige poster i sykekasser, kommuner og lignende. Personalia. Spørsmaal og svar. Smaa meddelelser. Bureauet.

'Tidsskrift for den norske lægeforening, tilstilles lægeforeningens medlemmer gratis. Ikke-medlemmer betaler i abonnement kr. 30,00 aarlig, porto iberegnet. Abonnement for ikke-medlemmer tegnes i ‘Tidsskriftet's ekspedition, Centraltrykkeriet, 'Toldbodgd. 31 . $\mathrm{Kr}$.ania.

Ang. annoncepriser for kundgjørelser for ind-og utland, se annonce-side 6 .

Las annoncernel Der er altid nye hver gang.

KRISTIANIA - CENTRALTRYKKERIET 1919

Som et uveir kom influenzaen over os siste sommer. (...) Efterhvert som ængstelsen blant befolkningen tiltok, blev forslagene i dagspressen til forebyggelse og behandling mere og mere talrike og indtrængende. Det var særlig diskussionen om værdien av alkohol som profylaktikum og terapeutikum, som optok interessen og litt efter litt tilspidset sig med fanatiske og lidenskabelige indlæg for og imot. - Nu, da stormen for denne gang er over og jeg efter de vundne erfaringer stiller mig det spørsmaal: Har vi i alkohol eller andre medikationer et virksomt profylaktikum likeoverfor influenza, som vi kan peke paa og anbefale til saadant bruk, naar den næste epidemi engang maatte komme?-, maa svaret fra 
min erfaring desværre bli et avgjort: nei! Det positive, jeg mener vi har lært, er, at sygdommen efterlater immunitet hos de fleste mennesker; men vi har ogsaa lært det negative, at vi hittil ikke kjender et eneste paalidelig profylaktikum mot influenza.

Der spørres: Men hvorav kommer det saa, at mange, som anvendte en dosis kognak, kinin eller noget andet daglig, holdt sig friske, mens deres omgivelser laa syke rundt dem paa alle kanter? Og hvorfor forblev en del friske i den tid, hvor de brukte alkohol og var utsat for smitte, mens de fik sygdommen senere paa et tidspunkt, hvor dette profylaktikum ikke blev anvendt? Hertil vil jeg svare med et andet spørsmaal: Hvorav kommer det, at en del av pleiepersonalet paa Ullevaal i sommer og i høst uten nogetsomhelst profylaktikum gik omkring og stelte med de mange daarlige og haardt angrepne patienter i maanedsvis uten selv at bli syke; men saa en vakker dag fik ogsaa enkelte av disse sygdommen? Antagelig fordi mottageligheten paa siste tidspunkt av en eller anden grund var tilstede eller større. Hypotetisk kan det tænkes, at en medfødt eller erhvervet uimottagelighet eller immunitet paa et givet tidspunkt er opbrukt eller svækket. Der vil da komme anslag, hvis man blir smittet, paa samme maate som der kan komme anslag med kokoppevakcine f. eks. ved en senere revakcination hos et individ, som nogen maaneder i forveien viste sig immun for saadan vakcine. Immuniteten er med andre ord opbrukt og mottagelighet er tilstede. At paavirke den individuelle mottagelighet i positiv eller negativ retning ved influenza ved hjælp av alkohol er neppe rimelig.

\section{«Den eneste effektivt forebyggende forholdsregel er at holde infektionsmuligheten borte»}

Den eneste effektivt forebyggende forholdsregel er at holde infektionsmuligheten borte. Dette er som bekjendt meget vanskelig, hvor man har med en pandemi av en saa yderst infektiøs sygdom som influenza at gjøre. Isolation i større samfund har vist sig umulig at gjennemføre, ialfald før en større del av befolkningen har gjennemgaat sygdommen og derved er immunisert, saa tilfældene blir færre og foci mere spredt. Om bruk av masker eller nytten av terpentinskaaler i sykeværelserne, som har været foreslaat, har jeg ingen personlig erfaring. Et desinficerende mundtoilette er høist anbefalelsesværdig, men ikke forebyggende.

\section{"Alkohol som medikament i disse tilfcelder harjeg aldrig fundet grund til at forordne»}

Jeg har dog ikke altid fundet grund til at beta det ængstelige publikum troen paa et eller andet profylaktisk adjuvans - ogsaa alkohol - idet et saadant - hypotetisk set - i enkelte tilfælder ved sin psykisk beroligende indflydelse maaske kan tænkes at virke heldig utløsende paa den i øieblikket netop nødvendige reserve av motstandskraft hos en organisme med vippende immunitetsballance, og hvor ængstelse, haabløshet og depression maaske kunde ha den motsatte virkning.

(...) Det vigtigste ved behandlingen er at søke forebygget komplikationer, specielt pneumonier, og her er et tilstrækkelig langvarig sengeleie av overordentlig betydning. Alkohol som medikament i disse tilfælder har jeg aldrig fundet grund til at forordne; men vi har ikke saa sjelden faat til behandling i sykehuset daarlige patienter med pneumoni, som i hjemmet hadde faat til dels ganske store doser alkohol uten nogensomhelst forebyggende virkning likeoverfor utbruddet av pneumonien. (...)

Publisert: 8. november 2021. Tidsskr Nor Legeforen. DOI: 10.4045/tidsskr.21.0461

(C) Tidsskrift for Den norske legeforening 2023. Lastet ned fra tidsskriftet.no 26. april 2023. 